\title{
Finance: Economic Lifeblood or Toxin?
}

\author{
Marco Pagano \\ University of Naples Federico II, EIEF and CEPR \\ Preliminary version
}

26 October 2012

\begin{abstract}
In the past two decades, academic research has produced a massive amount of evidence highlighting the beneficial role of financial development for growth and for the allocation of investment. Yet, our current vision is dominated by instances of dysfunctional behavior of financial markets associated with acute and widespread crises. This begs the issue of when and why finance stops being the "lifeblood" and turns into a "toxin" for real economic activity. This paper is a tentative first step in this direction. It highlights that this metamorphosis appears to occur when finance becomes "too large" relative to the underlying economy: it then stops contributing to economic growth and starts threatening the solvency of banks and systemic stability. A related question is why regulation is not designed so as to prevent the financial industry from growing above this threshold. I argue that a large part of the answer lies in the symbiosis between politicians and the finance industry.
\end{abstract}

Keywords: financial development, financial crisis, risk taking, market failure, political economy.

JEL classification numbers: G01, G18, G21, G28, H81, O16.

* Paper prepared for the CEPR-Chicago Fed Annual International Banking Conference on "The Social Value of the Financial Sector: Too Big to Fail or Just too Big?," Chicago, 15-16 November 2012. I thank Andrew Ellul for his helpful comments, Alessio Piccolo for outstanding research assistance, Viral Acharya and Robert Capellini (NYU-Stern) for providing measures of systemic risk, and EIEF for research funding. 


\section{Introduction}

MBA or PhD students attending their first asset pricing classes are typically presented with a picture of finance as an efficient allocation machine that puts capital to its best possible use and allows people to share efficiently all kinds of risks. Yet nowadays, upon walking out of their classroom, the same students need to read no further than the front page of the Financial Times or the Wall Street Journal to see financial markets and intermediaries being indicted as the culprits of giant misallocation of resources, witnessed for instance by huge empty real-estate developments in the U.S., Ireland and Spain, massive losses for the banks that funded them, and crippling tax bills for the taxpayers in order to bail out these banks. The same media also routinely point to banks and security markets as being the very source of huge risks, rather than efficient devices to trade and share the risks generated by production activity and natural events.

Such contrasting attitudes towards financial markets have been present in the writings of economists for decades, with each side fighting for the minds and hearts of generations of students and colleagues. What today makes the contrast more strident is the increased visibility of finance and the enormity of the current crisis (though not even these are entirely novel features, looking back at the role of finance in the Great Crisis of the 1930s).

Economists have long considered banks and securities markets as providing the lifeblood of the economy: more specifically, as essential prerequisites for economic growth. For instance, John Hicks (1969) argued that the development of liquid capital markets - and not technical progress per se - is what made the industrial revolution possible: "According to Hicks, the products manufactured during the first decades of the industrial revolution had been invented much earlier. Thus, technological innovation did not spark sustained growth. Many of the existing innovations, however, required large injections and long-run commitments of capital. The critical new ingredient that ignited growth in eighteenth century England was capital market liquidity" (Levine, 1997, p. 692). As we shall see below, the view that finance promotes growth is supported by a vast and solid body of research work.

However, more critical voices have been present among economists at least since Keynes (1936), who warned that financial markets can lead to inefficient investment decisions, by encouraging short-term speculation rather than sound investment choices based on firms' long-term prospects: "If I am allowed to appropriate the term speculation for the activity of forecasting the psychology of the market, and the term enterprise for the activity of forecasting the prospective yield of assets over their whole life, it is by no means always the case that speculation predominates over enterprise. As the organization of investment markets improves, the risk of the predominance of speculation does however increase... These tendencies are a scarcely avoidable outcome of our having successfully organized 'liquid' investment markets. It is usually agreed that casinos should, in the public interest, be inaccessible and expensive. And perhaps the same is true of Stock Exchanges " (p. 158-9). Keynes' viewpoint was echoed by a handful of later researchers, such as Hyman Minsky, who in the 1960s and 1970s argued that credit markets are inherently prone to boom-bust cycles driven by the irrational expectations of bankers and investors, and Robert Shiller, who since the 1980s has argued 
that stock and housing prices are often driven by fads leading to bubbles and crashes. The recurrent financial crises of the last decades, recently culminating in the subprime crisis in the U.S. and the debt crisis in the euro area, have led increasing numbers of economists to realize that in some circumstances the operation of financial markets pose severe threats to real economic activity generating massive misallocation of resources and bubble-driven expansions followed by violent deleveraging and sharp recessions.

Broadly speaking, this dysfunctional behavior of financial markets has been interpreted as stemming from one of two root causes. To some, bubbles and crashes arise from investors being guided by irrational (or not completely rational) beliefs: this strand of research - known as "behavioral finance" - is essentially a derivation of the Keynes-Minsky-Shiller line of thought. To others, the problem has to do with the incentives of bankers, asset managers and investors arising from their contractual relationships and even more from misguided regulation and monetary policy. For instance, the excessive credit boom and lending standards deterioration before the recent crisis is blamed on the emergence of an unregulated shadow banking system funded by securitizations (Adrian and Shin, 2010), on very loose monetary policy (Dell'Ariccia, Igan and Laeven, 2012, Maddaloni and Peydrò, 2011), and on the expectation of bailouts by policy makers (Fahri and Tirole, 2012). This view naturally begs the question of why policy makers choose policies and regulations with such perverse incentive effects on behavior of financial markets, i.e., raises issues about the political economy of financial regulation.

But, while our current vision is dominated by instances of dysfunctional behavior of financial markets, we should not forget the massive amount of evidence highlighting their beneficial role for growth and for the allocation of investment. Hence, the key issue is to understand when and why finance stops being the "lifeblood" and turns into a "toxin" for the economy. This paper is a tentative first step in this direction. It highlights that this metamorphosis appears to occur when and because finance becomes "too large" relative to the underlying economy.

In the initial phase of economic development, for instance in Britain during the industrial revolution and in many developing countries nowadays, improvements in the financial system typically benefit real economic activity. In these early stages, firms are typically subject to binding financing constraints, so that lifting institutional barriers to financial development enhances the availability of external finance to them and prods real economic growth. For instance, reforms that improve the enforcement of credit contracts or allow the entry of better-managed banks allow an expansion of credit, output and employment. Notably, such reforms might be associated with a better selection of borrowers, and therefore fewer insolvencies.

However, as the availability of external finance available expands, the fraction of financially constrained firms decreases, so that further improvements in access to finance bring about smaller and smaller increases in output and employment. Indeed, once firms are no longer financially constrained, further increases in credit become unwarranted. However, at this point financial regulation and/or monetary policy may still induce banks to expand credit beyond the funding needs 
of solvent firms and households, for instance by creating the expectation that banks will be bailed out if eventually they become insolvent. Beyond a critical credit/GDP ratio, therefore, further increases in external financing should be associated with no significant increases in real economic activity, lower credit quality, and possibly even systemic instability.

Section 2 of this paper casts this idea of a non-monotonic relationship between financial development and real economic activity against the backdrop of the literature: after a brief summary of the vast body of research on finance and growth, I review a number of recent contributions that highlight why financial markets may become both "hypertrophic" and dysfunctional in their effects on the real economy. Section 3 presents some evidence about this non-monotonic relationship, by looking first at the relationship between financial development and economic growth and then at its relationship with indicators of bank solvency and of systemic instability. Section 4 concludes by asking why regulation should ever let the dark side of financial development emerge, rather than containing it within bounds that make it beneficial: in other words, it ventures into the political economy of financial regulatory failures.

\section{A mixed record: the literature}

Although economists are well-known to find it hard to agree about almost anything, ${ }^{1}$ in the last two decades the idea that credit and security market development is conducive to economic growth has gained a broad and solid consensus, buttressed by an impressive body of evidence based on disparate data sets. But the recurring crises of the last decade are currently prompting a reconsideration of the effects of financial development, and in particular a growing awareness that in some situations it may far exceed the needs of the real economy, and actually lead it to severe misallocation of resources and unnecessary volatility in output and employment. This section contrasts the bright record that finance earned in most of the earlier academic literature (Section 2.1) with the darker side of the picture that has received more attention lately (Section 2.2).

\subsection{The bright side}

A large stream of research has investigated the real effects of financial development, both in terms of the breadth of financial markets and in terms of their efficiency in allocating capital. This research has identified various sources of financial development. Liberalization may allow the entry of new and possibly more sophisticated intermediaries, resulting in cheaper and more abundant finance. Legal reform to strengthen creditor or shareholder protection may reduce moral hazard in lending or in the provision of equity capital, thus easing firms' financial constraints. In all these cases, financial

\footnotetext{
${ }^{1}$ In Winston Churchill's words: "If you put two economists in a room, you get two opinions, unless one of them is Lord Keynes, in which case you get three opinions."
} 
development tends to increase the external funding available to firms, facilitating business start-ups and expansion. Financial development can also assist growth by allocating capital more efficiently, channeling more resources to the more promising projects and thus boosting aggregate productivity. ${ }^{2}$

The positive correlation between indicators of financial development and economic growth is well established at least since Goldsmith (1969). But obviously correlation does not establish causality. To establish whether financial development contributes to growth, researchers have used econometric techniques and identification strategies to control for possible feedback of growth on financial development, using three types of data: country-level, industry-level, and firm-level.

Using country-level data, King and Levine (1993a, 1993b) relate economic growth rates to measures of lagged financial development in 80 countries. Their main finding is that all the indicators of economic performance are positively associated with the predetermined component of financial development, defined as the size of the financial sector at the beginning of the sample period. However, the use of predetermined variables to measure financial development only partly overcomes endogeneity problems. An omitted common variable could still drive both long-run growth and the initial level of financial development, generating a spurious correlation. To resolve this problem, researchers have sought instruments that are unquestionably exogenous. Some scholars have selected the type of legal system, which La Porta, Lopez-de-Silanes and Shleifer (1998) show to be correlated with the size of a country's financial market. Legal systems can be considered as exogenous because they were created centuries ago and spread mainly through occupation and colonialism. Beck, Levine and Loayza (2000a) accordingly use legal origin as instrument for financial development, and again find that the size of the financial sector is positively correlated with the growth of per capita GDP and of total factor productivity - a result corroborated and extended by other studies including Beck, Levine and Loayza (2000b) and Demirguc-Kunt and Levine (2001).

Another strand of inquiry relies on industry-level data to address causality, on the assumption that financial market development should be more beneficial to the growth of industries that are more dependent on external finance. Rajan and Zingales (1998) construct their test by first identifying each industry's need for external finance from U.S. data (on the assumption that the U.S. financial system is highly developed) and then interact this industry-level "external dependence" variable with a countrylevel measure of financial development. They then include this interacted variable in a regression for industry-level growth, where its coefficient should capture the severity of constraints on growth due to degree of financial development, using fixed effects to control for time-invariant country and sector characteristics. Applying this approach to industry-level data for a large sample of countries in the 1980s, they find that measures of financial development do indeed affect economic growth disproportionately in externally dependent industries.

\footnotetext{
${ }^{2}$ Pagano (1993) provides a simple framework capturing the effects of financial development on both the rate of capital accumulation and on the efficiency of its allocation, and briefly reviews the theoretical foundations of both effects, as well as the early empirical literature on finance and growth. Levine (2005) contains a more up-to-date review of this literature.
} 
Further evidence on the nexus between finance and growth comes from firm-level data. Guiso, Sapienza and Zingales (2004) find that in Italy local financial development, as measured by selfreported information on households' access to credit, increases an individual's probability of starting a business, the ratio of new firms to the population, the growth rate of firms over and above internally financed growth, and per capita GDP. They control for the potential endogeneity of financial development by instrumenting their indicator with bank branch density as determined by regulation in 1936. Guiso, Jappelli, Padula and Pagano (2004) apply the Rajan-Zingales approach to data for companies in the EU and in Central and Eastern Europe, producing firm-level estimates consistent with those of studies based on industry-level data and finding that financial development fosters the growth of smaller firms in particular. Firm-level data have also been used to detect the impact of financial development on market entry for small businesses. Aghion, Fally and Scarpetta (2007), applying the Rajan-Zingales approach to firm-level data in 16 industrial and emerging economies, find that financial development encourages entry by small firms in the sectors that are most dependent on external finance. And Klapper, Laeven and Rajan (2006) show that in Europe financial development favors entry in the sectors that are relatively dependent on external finance.

A particularly convincing way of addressing the issue of causality exploits the "quasi-natural experiments" offered by specific (and arguably exogenous) changes in financial market regulation. For instance, Jayaratne and Strahan (1996) document that the relaxation of U.S. geographical restrictions on bank expansion between the 1970s and the early 1990s was associated with faster local economic growth. Dehejia and Lleras-Muney (2007) document the same relationship with earlier data, showing that changes in state-level banking regulation between 1900 and 1940 were also associated with higher growth, after controlling for factors that could confound a causal interpretation of the correlation. Bertrand, Schoar and Thesmar (2007) find that the deregulation of the French credit market triggered by the Banking Act of 1985 was associated with greater asset and job reallocation at the industry level, and better allocation of capital across firms: banks became less willing to bail out poorly performing firms, while firms in bank-dependent sectors became more likely to restructure.

Related evidence comes from the analysis of stock market liberalizations, i.e., policies relaxing restrictions on foreign investors' share purchases. These policies are associated with an increase in liquidity, a jump in stock prices and a drop in the cost of equity capital, as well as an increase in private investment. For instance, in a sample of 11 developing countries that liberalized their stock markets, Henry (2000) finds that the growth rate of private investment rose above the median preliberalization investment rate in 9 countries one year after, in 10 two years after and in 8 three years after liberalization. The average growth rate of private investment in the three years after liberalization exceeds the mean of Henry's sample by 22 percentage points. Similarly, Bekaert, Harvey and Lundblad (2005) show that equity market liberalization is associated with a subsequent average annual real economic growth of about $1 \%$, and that this effect is robust to controls for capital account liberalization and other simultaneous reforms. Effects of similar magnitude have been documented at the sector level by Gupta and Yuan (2009), who document industries that are more externally dependent and face better growth opportunities grow faster following liberalization. 


\subsection{The dark side}

Several recent papers have highlighted that in the years before the subprime crisis the U.S. and several European countries featured not only a bubble in the housing and securities markets, but also an abnormal growth in private credit and in the leverage of financial institutions. Indeed, the two phenomena - the asset price bubble and the over-expansion of credit - appear to have robustly fed on each other, reinforcing their respective effects. Researchers have identified three key motives for this hypertrophy of finance: (i) the birth of an unregulated "shadow banking system" funded by securities markets and especially securitizations, (ii) a lax monetary policy both in the U.S. and in Europe, leading to abundant liquidity and very low interest rates, especially between 2002 and 2005, and (iii) the widespread expectation that, faced with widespread financial distress, policy-makers would bail out financial institutions with abundant liquidity and capital injections - as indeed is still happening in the U.S., in Europe and more recently also in China.

\subsubsection{Shadow banks and securitization}

The development of shadow banks has been especially prominent in the U.S., where a variety of intermediaries managed to secure massive funding via the issuance of securities rather than via access to deposits, and therefore had no explicit access to central bank liquidity or public sector guarantees: as explained by Pozsar, Adrian, Ashcraft and Boesky (2010), shadow banks include finance companies, asset-backed commercial paper conduits, structured investment vehicles, credit hedge funds, money market mutual funds, securities lenders, limited-purpose finance companies, and government-sponsored agencies such as Fannie Mae and Freddie Mac. The development of these shadow banks created a more direct link between asset prices and credit than that already existing in commercial banking: as pointed out by Adrian and Shin (2010), the growth in asset prices expanded the net worth of these financial intermediaries, with very large multipliers owing to their very high leverage, and allowed them to expand their balance sheets; in turn, this put further pressure on asset prices, and led to a further increase in the net worth and balance sheet of intermediaries. In other words, in the pre-crisis period the asset price bubble and the expansion of the balance sheets of financial intermediaries fed on each other, leading to a boom. And the same process has operated in reverse as soon as asset prices (starting with housing) started to decline in 2007.

Indeed Greenwood and Scharfstein (2012) documented that the tremendous growth of the U.S. financial industry in the last three decades - from 4.9\% of GDP in 1980 to $7.9 \%$ in 2007 - resulted chiefly from the expansion of the asset management sector and of the household credit sector, and was fueled precisely by the "shadow banking system" and the securitizations process. This also explains the results by Philippon (2008), who models the relationship between the financial sector and the real economy in an overlapping-generations setting, where people choose between working in banks or firms, and banks can mitigate firms' financing constraints. When calibrated to U.S. data, Philippon's model fits quite well the evolution of the U.S. financial sector for most of the past 150 
years, except for the last decade, where it greatly underpredicts its relative size. This underprediction might be precisely due to the fact that the model neglects the household demand for financial services, as well as the innovations in the U.S. financial industry that have occurred in the last decade.

This hypertrophy of the U.S. financial industry has correlated with an increasing remuneration of its employees. Philippon and Resheff (2008) find that this increase in compensation has been concentrated in asset management and investment banks, that is, precisely the sectors most closely involved in the growth of the "shadow banking system": in these two sectors salaries, which in the early 1980s were aligned with those of other (non-farm) workers, by 2007 had become 4 times as large. Both phenomena - financial market hypertrophy and very high salaries - could stem from the opacity of the relevant financial markets, according to the model by Bolton, Santos and Scheinkmann (2012): insofar as more opaque markets attract the workers who are best at evaluating deals, they also manage to "cream-skim" the best deals away from more transparent markets, and - again owing to their opacity - earn high rents from these deals. This result in very high salaries in the more opaque segments of the financial industry, and too much talent being allocated to information processing.

While it is indeed true that the securitization process that funded "shadow banks" was very opaque, it may be argued that it featured too little, rather than too much, information processing: investors in the market for asset-backed securities (ABS) were fed very scant information regarding the underlying asset pools and risk characteristics of ABS payoffs, as witnessed by their massive underpricing in the pre-crisis years. In fact, Pagano and Volpin (2012) argue that ABS issuance was so opaque precisely to allow their placement with a broad set of investors: marketing large amounts of ABS meant selling them also to unsophisticated investors, who could not accurately process the information necessary to price them. In fact, if such information had been released, it would have put them at a disadvantage vis-à-vis the "smart money" that can process it. This created an incentive for $A B S$ issuers to negotiate with credit rating agencies a low level of transparency - that is, relatively coarse and uninformative ratings. Ironically, the elimination of some price-relevant information was functional to expand the market and support prices in the ABS new issue market. ${ }^{3}$

The extraordinary growth of shadow banks and securitizations before the crisis may have induced a deterioration of the quality of financial information for two other reasons as well. First, the very growth of $A B S$ issuance probably made it harder for credit rating agencies to resist engaging in opportunistic behavior, i.e. softening their standards to please issuers: there is evidence that the actual ratings for CDOs were inflated relative to those predicted by the rating agencies' models. For instance, Griffin and Tang (2011) analyze data from a major rating agency, and report that, by

\footnotetext{
${ }^{3}$ Di Maggio and Pagano (2012) show that issuers of complex securities may prefer opaqueness also to avoid giving a strategic advantage to sophisticated investors, which would depress the sale price: once information is disclosed, unsophisticated investors will worry that if the asset has not already been bought by others, it could be because more sophisticated investors, who are better at understanding this information, concluded that the asset is not worth buying. This depresses the price that unsophisticated investors are willing to pay; in turn sophisticated investors, anticipating that the seller will have a hard time finding buyers among the unsophisticated, will offer a price below the no-disclosure level.
} 
"adjustments" in its ratings, the agency increased the size of AAA rated tranches on average by $12.1 \%$, and CDOs with larger "adjustments" experienced worse subsequent performance. They conclude that, had the rating agency followed its own model before April 2007, 91.2\% of its AAA tranches would have been rated AA. ${ }^{4}$ Second, aside from opportunism, before the crisis rating agencies may have lowered their standards because they were overburdened by work: as pointed out by Bar-Isaac and Shapiro (2011), the agencies "lacked adequate staff, motivation, and quality personnel just at the time when their business was booming the most" (p. 1), and could not expand their staff with talented workforce in the face of keen competition from highly profitable investment banks.

\subsubsection{Low interest rates and drop in credit standards}

As already noticed, in the pre-crisis period shadow banks and securitizations gained great prominence in the U.S. financial system. Yet, the hypertrophic growth of finance has not been confined to the U.S.: to some extent it also occurred in Europe. For instance, in Ireland and Spain the feedback loop between house prices and credit expansion was as evident and violent as in the U.S. This underscores that another factor was at work before the crisis: very abundant liquidity and low interest rates.

A considerable amount of evidence indicates that such low interest rates encouraged banks to take larger and riskier bets in the "search for yield", both in lending activity and in proprietary security trading. Dell'Ariccia, Igan and Laeven (2012) document that during the subprime loan crisis the rapid expansion of credit went hand-in-hand with declining lending standards: these declined more in areas that experienced larger credit booms and house price increases, and in areas with higher mortgage securitization rates. Maddaloni and Peydrò (2011) analyze the determinants of bank lending standards in the euro area by relying on the answers from the Bank Lending Survey, whereby central banks request quarterly information on the lending standards that banks apply to customers. They document that low short-term interest rates soften lending standards for both businesses and households, especially if rates are held "too low for too long". In their estimates, they control for the improvement of borrowers' creditworthiness resulting from cheaper credit. They also find that securitization activity and weak banking supervision amplify the impact of low short-term interest rates on bank risk-taking. Of course, a great empirical challenge is to determine whether a low interest rate affects the riskiness of loans because it affects loan supply by banks or the demand for loans by firms and households. Jiménez, Ongena, Peydró and Saurina (2011) address this identification challenge by drawing data on loan contracts and applications from Spain's credit register since 1984, and using sophisticated panel data techniques to distinguish the changes in the composition of credit supply from those arising from changes in demand. They find that a lower overnight interest rate induces less capitalized banks to expand credit to riskier firms, to terminate

\footnotetext{
${ }^{4}$ See also Ashcraft, Goldsmith-Pinkham and Vickery (2010) and Griffin and Tang (2010). For a survey of the shortcomings of credit ratings agencies during the crisis, see Pagano and Volpin (2010).
} 
less often loans to risky firms, and to be more likely to extend loans to risky new applicants, granting them larger and longer-term loans. ${ }^{5}$

The reason why low interest rates may prompt banks to relax their lending standards and offer loans to riskier customers is well captured by the model of Acharya and Naqvi (2012), where moral hazard within banks induces excess risk taking that is exacerbated when bank liquidity is abundant. In their model, each bank faces random deposit withdrawals and, in case of liquidity shortfall, pays a cost, for instance because it has to engage in fire sales of assets or raise finance at penalty rates. Absent moral hazard, this penalty, together with the expected profits from funding projects, induces banks to choose a lending rate that appropriately reflects the risk of the funded projects. If however the loan officers' effort is unobservable, it is optimal to tie their compensation to the amount of loans they make, and randomly carry out a costly audit to verify whether they engaged in excessive lending and underpriced loans. The time-consistent audit policy is to audit the loan officer only when the liquidity shortfall suffered by the bank is sufficiently large. Hence, at times in which the bank can count on abundant liquidity, loan officers rationally anticipate a lenient policy of infrequent audits, and engage in excessive lending, i.e. charge a lending rate that underprices credit risk.

\subsubsection{Systemic bailouts, excessive lending and systemic risk}

The research just discussed is based on the idea that policy affects banks' behavior: lax monetary policy leads banks to engage in excess lending and lower their credit standards. Farhi and Tirole (2012) note that the causality may also go in the opposite direction: policy may be captive of the choices of financial institutions, since once these have become collectively overexposed to risk upon lending too much, the central bank has no other option but lowering interest rates and expanding liquidity to avert financial meltdown. In turn, as soon as they realize that policy makers are captive of their choices, banks have the incentive to engage in excessive lending and thus generate systemic risk. Hence, Farhi and Tirole (2012) take the notion of moral hazard to the collective, or systemic, level: the incentive to engage in excess lending exists for banks as a group, not just individually; by the same token, as each bank has the incentive to engage in excess lending, insofar as it expects others to do so. Otherwise stated, the policy-maker's expected response generates a strategic complementarity in banks' leverage decisions, and in turn these decisions make monetary accommodation ex-post optimal. The overall result is an excessive monetary accommodation, excess lending and risk-taking.

This model has a number of additional insights. One is that banks have the incentive to choose risks correlated with those chosen by other banks, since in a crisis there is "safety in numbers": a crisis that involves many banks is more likely to induce an accommodating policy response than one that is limited to a few institutions. Brown and Dinç (2011) document this "Too-Many-to-Fail" effect in a

\footnotetext{
${ }^{5}$ Ioannidou, Ongena and Peydrò (2009) also show that, when the U.S. federal funds rate is low, in dollarized Bolivia banks are more likely to extend loans with a subprime credit rating or loans to borrowers with a poor solvency record.
} 
study of bank failures in 21 emerging market countries in the 1990s: they show that governments are less likely to take over or close a failing bank if the banking system is weak, in the sense that other banks also have a low capital ratio.

Another insight concerns the fact that an accommodative policy response "plants the seeds of a new crisis", by reinforcing the expectation of a similar response in the future. This is reflected in the notion of "Greenspan's put": the Fed's consistently accommodating response to crises under Greenspan's chairmanship (from 1987 to 1990) was perceived as a guarantee that sharp drops in asset prices and widespread financial distress would prompt the Fed to lower the Fed funds rate and increase liquidity, and possibly coordinate bailouts of distressed institutions. The Fed did so after the 1987 stock market crash, during the 1994 Mexican crisis, the 1997 Asian crisis, the 1998 LTCM crisis, the 2000-01 burst of the dotcom bubble, and then massively during the subprime crisis and up to the present date, when interest rates have been lowered close to zero and accommodating policy has taken the form of (now open-ended) quantitative easing.

Indeed the only recent instance in which the Fed tried to break free of this accommodative policy pattern - the decision to let Lehman Brothers go bankrupt - witnesses the disruptions that occur upon deviating from the time-consistent equilibrium described by Farhi and Tirole (2012), and thus highlights the extent to which policy is hostage to banks' expectations. Of course, these insights go beyond monetary policy, since to some extent they also extend to other accommodative policies towards distressed banks, such as bailouts and recapitalizations funded by fiscal authorities.

Why policy makers let themselves be "trapped" in this equilibrium that features excess lending by banks, recurrent episodes of systemic risk, and far too accommodating policy responses? I leave this issue for the final section, and now turn to some evidence that brings out both the bright and the dark side of financial development, and indicates when each of them tends to manifest itself.

\section{The non-linear effect of financial development: some evidence}

In this section I explore whether the evidence is consistent with the idea that the real effects of financial development are non-linear. Merging the insights from the two strands of literature surveyed in Section 2, the working hypothesis is that initially the expansion of the financial industry tends to contribute to economic growth, without endangering the solvency of banks and systemic stability. Conversely, beyond a critical level finance makes no meaningful contribution to long-run growth, while it reduces bank solvency and creates systemic risk. Accordingly, in what follows I investigate two different data sets: one relevant for growth, and another for bank solvency and systemic stability. 


\subsection{Non-linear effect on long-run growth}

The approach used here takes after Rajan and Zingales (1998), which is based on the idea that the impact of financial development on growth should be heterogeneous across industries, depending on their technological need for external finance. Because dependence on external finance is unobservable, as in Rajan and Zingales (1998) it is measured by the reliance on external finance of U.S. listed companies in the Compustat database. The dependent variable is the average annual growth rate of real value added between 1970 and 2003, by sector and country. Denoting the dependent variable by $Y$, the baseline specification is:

$$
Y_{j c}=\delta\left(F D_{c} \times E D_{j}\right)+\gamma S H A R E_{j c}^{1970}+\mu_{j}+\mu_{c}+\varepsilon_{j c}
$$

where the subscripts $c$ and $j$ index countries and sectors, respectively, $F D_{c}$ is a country index of financial development as measured by the initial ratio of total credit and/or stock market capitalization to GDP, and $E D_{j}$ is industry j's external finance requirement. The variable $S H A R E_{j c}^{1970}$ denotes the industry's share of $Y_{c j}$ in the manufacturing sector in 1970. Fixed sector and country effects are denoted by $\mu_{j}$ and $\mu_{c}$, respectively, and $\varepsilon_{j c}$ is the residual. Fixed effects are included to rule out the possible spurious correlation between finance and real variables due to unobserved heterogeneity in country or industry characteristics.

The coefficient $\delta$ in equation (1) captures the effect of financial development on growth: it estimates the differential response to financial development in $Y_{c j}$ by industries with different external finance requirements. A positive and significant estimate of $\delta$ is consistent with the idea that financial development facilitates growth in sectors that are highly dependent on external finance. To allow this effect to differ between countries with different degree of financial development, in Table 1 equation (1) is also estimated separately for OECD and non-OECD members, since (based on the data) the latter countries tend to have a lower degree of financial development than the former.

The data are drawn from the UNIDO INDSTAT3 2006 database, which contains annual data for 28 three-digit industries on value added for the period 1970-2003. ${ }^{6}$ Hence, the sample does not include the years of the 2007-09 financial crisis. Since indicators of financial development are not available in many countries, at most data for 63 of the countries are used in the estimation. The United States is excluded from the analysis because it is our benchmark country. Additional observations are lost due to missing data, which somewhat reduces the final sample.

Table 1 presents the estimates, drawn from Pagano and Pica (2012). For comparability with the literature, financial development is measured by two indicators: the ratio of stock market capitalization to GDP (1980-95 average) and the ratio of private credit to GDP (1980-95 average). The estimates of $\delta$ reported in Table 1 show that in the entire sample a higher degree of financial

\footnotetext{
${ }^{6}$ The 2006 release is used because later releases have more missing observations, particularly for developing countries.
} 
development is associated with a higher growth rate of value added of the sectors that depend more on external finance. However, Table 1 also shows that in the subsample of OECD countries financial development has no significant impact on the growth of value added: for these countries, the estimates of $\delta$ are small and not significantly different from zero. In contrast, the estimates for nonOECD countries indicate that financial development spur the growth of value added. ${ }^{7}$ This suggests that the results for the whole sample are driven by the non-OECD countries, where firms are more likely to be finance-constrained. ${ }^{8}$ Hence, the evidence that financial development benefits growth is confined to countries where financial development is at a relatively early stage, so that an expansion of the financial industry tends to be associated with improved access to finance for the local firms. Beyond a certain point, financial development does not appear to contribute significantly to real economic activity. Indeed, there are even recent contributions that show that beyond a certain threshold it has a negative effect on growth: Arcand, Berkes and Panizza (2012) produce country- and industry-level evidence that finance has a negative effect on output growth when credit to the private sector grows above 100\% of GDP; similarly, Ductor and Grechyna (2011) find in OECD data that when financial development exceeds the growth of real-sector industries by $4.5 \%$, their correlation turns negative, and attribute this non-linearity to financial crises.

Indeed, there is evidence that financial development increases the sensitivity of output and employment to banking crises: using the Rajan-Zingales approach, Kroszner, Laeven and Klingebiel (2007) find that during banking crises sectors that depend heavily on external finance suffer a sharper output contraction in countries with a higher degree of financial development, and Pagano and Pica (2012) find a similar result for employment. Yet, neither study includes data for the post-2007 recession in the estimation. We now turn to some evidence regarding the relationship between financial development and financial stability, where instead data from the recent crisis play a key role.

\subsection{Non-linear effects on bank solvency and systemic stability}

Beside affecting the long-run growth rate, financial development may affect the solvency of banks and the stability of the banking system. As already argued, insofar as an expansion in lending simply relieves the financial constraints of solvent firms, it need not lead to deterioration in credit quality. But if banks are awash with liquidity, they are likely to end up extending loans to bad risks or

\footnotetext{
${ }^{7}$ Similar results are obtained by re-estimating these regressions on the original data set used by Rajan and Zingales (1998). In those data too the correlation between financial development and growth obtains only for non-OECD countries.

${ }^{8}$ The non-linearity of the effect of financial development on growth also emerges if one estimates a specification in which financial development enters both in level and in squared form: consistently with the predicted non-linearity of its effects, the coefficient of the linear term is positive and that of the quadratic term is negative, and both are significantly different from zero if financial development is measured by private credit/GDP. However, neither one is significantly different from zero if it is measured by stock market capitalization/GDP. Pagano and Pica (2012) find the same non-linearity also in the effect of financial development on employment growth.
} 
underpricing credit risk, as suggested by the model of Acharya and Naqvi (2012) and by the evidence described in Section 2.3. In this case, the expansion of credit will lead to bank distress and may even endanger systemic stability.

To explore the relationship between the creditworthiness of banks and credit market development, I rely on the 2012 update of the Financial Structure Dataset constructed by Beck and Demirgüç-Kunt (2009) and Čihák, Demirgüç-Kunt, Feyen and Levine (2012), and containing data for 203 countries from 1960 through 2010. The creditworthiness of banks is measured by their "Z-score" variable, i.e. the sum of return on assets (ROA) and equity/assets ratio, divided by the standard deviation of ROA, based on underlying bank-by-bank unconsolidated data from Bankscope. Unfortunately this variable is available (at best) since 1997. Credit market development is measured by the private credit issued by deposit money banks and other financial institutions, scaled by GDP.

A visual inspection of the data is quite revealing. Figure 1 shows the two variables for selected countries where the credit-GDP ratio does not exceed the 50\% threshold throughout the 1997-2010 sample period. The credit-GDP ratio is measured along the left axis, and the Z-score along the right axis of each plot. Almost all of the countries in the various panels of Figure 1 are developing countries. In most of them, the two variables appear positively correlated, although there are instances in which the correlation is negative (such as Burkina Faso, Ecuador, Georgia, Kazakhstan and Venezuela) or unclear (such as Ghana, Kenya, Mexico and Senegal). This suggests that in countries that start from a relatively low level of financial development, credit expansion does not necessarily correlate with a drop in the domestic banks' creditworthiness. The positive correlation that emerges for many countries may arise from a boost in firm growth and profitability calling for an expansion in credit and simultaneously allowing banks to increase their profits and strengthen their capital base.

A very different picture emerges from Figure 2, which shows the same two variables for selected countries where the credit-GDP ratio exceeded the $50 \%$ threshold at least once in the sample period. In almost all countries in this subsample, the correlation between the two variables is negative (one clear exception being Australia). It is interesting to notice that the correlation tends to become negative in particular after the credit-GDP ratio crosses a high threshold, which appears around $100 \%$ in the cases of Austria, Canada, Denmark, Germany and United Kingdom, between $70 \%$ and $80 \%$ for Belgium, Finland, France and Portugal, and 90\% for Korea. The countries that experience the sharpest drop in the Z-score are those in which the credit-GDP ratio increases the most, often reaching spectacular levels: from $137 \%$ to $270 \%$ in Cyprus, from $26 \%$ to over $105 \%$ in Greece, from $41 \%$ to $272 \%$ in Iceland, from $64 \%$ to $238 \%$ in Ireland, from $78 \%$ to $210 \%$ in the Netherlands, and from $44 \%$ to $186 \%$ in Portugal. Other countries offer interesting examples in the opposite direction: both the Czech Republic and Japan feature a sizable reduction in the credit-GDP ratio - from $70 \%$ to $30 \%$ between 1994 and 2003 in the former, and from over 230\% to $170 \%$ between 1999 and 2010 in the latter and over the same period in both countries the Z-score of their banks improves enormously. 
The visual impression conveyed by these figures is confirmed by the panel regressions shown in Table 2 , where the Z-score is regressed on the previous year's credit-GDP ratio. The explanatory variable is lagged in order to reduce potential reverse causation: in principle, lower bank creditworthiness may call for an accommodating policy by the central bank, leading to a credit expansion. All regressions include fixed country effects, to control for unobserved heterogeneity across countries, and calendar year effects, to account for worldwide fluctuations in bank profitability, especially during the crisis.

The sample includes 166 countries, i.e. all the countries for which the 2012 version of the Financial Structure Dataset contains at least two observations for both variables (except for the non-market economies of North Korea, Laos and Libya, which are excluded). Due to missing observations for the dependent variable, for any given country the sample spans at most the period from 1997 to 2010. The coefficient of the credit-GDP variable is negative for the whole sample, but this result stems from the subsample of countries with high credit-GDP ratio: the coefficient is not significantly different from zero in the subsample of countries where private credit is below $50 \%$ of GDP. The coefficient for the whole sample and for the subsample of more financially developed countries is economically significant: within the subsample of more financially developed countries, a one-standard-deviation increase in the credit/GDP ratio (49.6, which is not uncommon in these countries, as shown by Figure 2 ) is associated with a 5.75 decrease in Z-score, i.e. $28.6 \%$ of its mean (20.1) in this subsample.

Table 3 investigates the relationship between private credit and systemic stability, and uncovers a similar non-linearity. The measure of systemic risk used in the regressions of Table 3 is an estimate of the capital shortfall that banks are expected to incur in a financial crisis, based on work by Brownlees and Engle (2012) and Acharya, Engle and Richardson (2012). Even though this estimate is produced using publicly available information, it is conceptually similar to those obtained via stress tests by U.S. and European regulators, and takes into account the correlation between the value of each bank's assets and the aggregate financial sector in a crisis. The estimates are updated weekly by VLab and posted at http://vlab.stern.nyu.edu/welcome/risk. More precisely, the dependent variable in the regressions of Table 3 for a given country and year is the sum of the capital shortfall of the banks considered in the VLab database for that country and year, scaled by their total stock market capitalization. The explanatory variables are the lagged credit/GDP ratio, country effects and year effects, as in Table 2 . The maximum estimation period is $2000-11$, since the VLab estimates are available for the 2000-12 interval, and credit/GDP data until 2011.

In the entire sample, systemic risk is positively correlated with the credit-GDP ratio, consistently with the results of Table 2: a credit expansion is associated not only with less creditworthy banks, but also with a more unstable credit system. But again, the relationship is statistically significant only for countries with high credit-GDP ratio. Interestingly, for this subsample of countries the estimate in Table 3 predicts that a 1-standard-deviation increase in credit/GDP is associated with an increase in 
systemic risk of 0.362 , which is $88 \%$ of its mean $(0.412)$ in this subsample. In other words, it almost leads to a doubling of systemic risk. ${ }^{9}$

\section{Why did regulation fail to prevent financial hypertrophy?}

As shown by Section 2.2, much recent research points to flaws in financial regulation and monetary policy as the source of the financial hypertrophy in developed countries: regulation is chiefly blamed for allowing the unfettered growth of the shadow banking system, and lax and accommodative monetary policy for inducing banks to over-expand credit and lower lending standards.

\section{1. "Sins of omission": neglecting financial innovation and changing incentives}

Many of the regulatory failures are "sins of omission" in the face of fast-paced financial innovation, such as that leading to the growth of shadow banks and of securitization. Some of these "sins" arise from the regulators' inertia in relying on tools that had proved to be effective in different settings but became dysfunctional owing to the growth of new markets. One example is the extensive delegation by prudential regulation to credit ratings, which had proved to be a reasonably effective gauge of credit risk in corporate bond markets, but became unreliable once applied to the much more complex securities that emerged in the securitization process: yet, prudential regulators simply reproduced in this area the pattern of delegation to credit rating agencies that they had applied to corporate bonds.

Another example concerns the LIBOR market, the reference rate set by London-based banks in the unregulated Eurodollar market since the late 1950s. Gradually over time, the LIBOR has become the reference point for an enormous amount of financial contracts and derivative markets, so that the banks that contributed to set LIBOR were often parties to contracts indexed to LIBOR - creating an obvious conflict of interest. Yet policy-makers neglected the need to oversee the rate-setting process, until in June 2012 criminal investigations uncovered that banks engaged in significant fraud and collusion in their rate submissions.

The similarity between the two examples is that an indicator (be it a credit rating or a LIBOR rate submission) that is reliable in the context of a specific market (the corporate bond or the Eurodollar market, respectively) will stop being reliable once it becomes the reference point of new, more

\footnotetext{
${ }^{9}$ Some of the countries included in the sample used in the regressions of Table 2 and 3 are offshore financial centers, which specialize in providing financial services to other countries, and on this account tend to feature a larger credit/GDP ratio than other countries. In principle, in these countries bank creditworthiness and systemic stability may have a difference relationship with the respective credit/GDP ratio. Therefore, for both Table 2 and Table 3,1 have also estimated specifications that include an interaction variable allowing the slope coefficient of credit/GDP to differ between financial offshore centers (according to the IMF classification) and other countries. The results are qualitatively unchanged relative to those shown in Tables 2 and 3, and therefore are not reported for brevity.
} 
sophisticated and much broader markets, because the greatly increased stakes make conflicts of interest and fraudulent behavior far more likely - essentially an incentive-based version of Goodhart's Law. ${ }^{10}$ If regulation is not updated to take into account that the very growth in financial markets alters the incentives of market participants and thus endangers the reliability of the indicator, then regulation itself ends up contributing to the dysfunctional behavior of financial markets.

\section{2. "Sins of commission": the role of politics}

However, regulation has contributed to financial hypertrophy also by "sins of commission". In some cases, these flaws have arisen from regulations aimed at correcting some inefficiency: a leading example is deposit insurance (and more generally the explicit and implicit guarantees given to banks), which were introduced to prevent bank runs, but ended up contributing to excess risk taking by bank managers, and more generally have created an implicit subsidy to banks, leading to excess capacity (overbanking) that in turn induces banks to compete too aggressively in search for yield.

Many "sins of commission" of regulators have been prompted by politics, which has had a considerable, yet insufficiently recognized role in planting the seeds of recent crises. For instance, in the U.S., the political determination to support widespread homeownership induced governmentbacked agencies such as Fanny Mae, Freddie Mac and AIG to guarantee low-quality loans in the securitization process, which hugely contributed to the subprime credit explosion and to the house price bubble. The same can be said of the 2001 decision by the Federal Deposit Insurance Corporation (FDIC) to reduce from $8 \%$ to $1.6 \%$ the capital requirement of banks on their investments in MBSs and in most CDOs issued by non-governmental entities and rated AA or better (to be compared to the $4 \%$ requirement applying to mortgages and lower rated mortgage securities), thus creating a huge inducement for banks both to securitize their loans and to invest in highly rated asset-backed and mortgage-backed securities. Similarly, in Europe, the decision by the EU Commission to exploit the "carve-out option" of Basel II regarding prudential ratios on sovereign debt has led EU banks to apply a zero risk weight on all of their euro-area sovereign debt holdings. This has encouraged banks to buy EU sovereign debt, especially debt featuring high yields and high risk. While this has certainly facilitated the national Treasuries in the placement of risky public debt, it has contributed to the riskiness of euro-area banks (Acharya and Steffen, 2012).

One of the most spectacular instances in which politics contributed to the hypertrophy of finance before the burst of the subprime bubble occurred in Iceland. Benediktsdottir, Danielsson and Zoega (2011) describe how in Iceland politicians provided key support to the almost incredible transformation of a tiny fishing and aluminum-producing economy into a platform of international banking, just in time to become a protagonist in the debt explosion and asset price bubble of 2003-07

\footnotetext{
${ }^{10}$ According to Goodhart's Law, once an economic indicator is made a target for the purpose of conducting economic policy, it will lose the information content that would qualify it to play that role.
} 
as well in the subsequent catastrophic collapse. They explain how politicians first privatized the banks by selling them to friendly businessmen (who took loans from those very banks to fund their stake acquisitions), and then jointly with these cronies dreamt up and carried out the plan of transforming Iceland in an international financial center. A crucial ingredient in the plan was the implicit sovereign support that the Icelandic government gave to the banks' record borrowing in 2004-05, a support that allowed them to access abundant funding in international markets at cheap interest rates. No less importantly, politicians failed to equip their fledgling financial center with adequate supervisory authorities, so that soon banks dwarfed the agencies that should have supervised them.

Spain is another instance in which the regulators' failings are largely rooted in politics: the huge capital inflow into Spain during the pre-crisis years was mediated by a social coalition formed by the managers of the Cajas, regional politicians and real estate developers, reciprocally supporting each other with favors and easy credit. This coalition channeled a huge amount of credit towards real estate, generating a large amount of bad loans and fostering the housing bubble: Cuñat and Garicano (2009) show that Cajas where chief executives had no previous banking experience, no graduate education and strong political connections extended more loans to real estate developers and fared substantially worse both before and during the crisis. The tight connection between politicians and the managers of the Cajas even affected the slow and ineffective response of Spanish prudential regulator to the crisis, and the protracted forbearance of bad loans to real estate developers. As Luis Garicano (2012) puts it, "the main explanation for the supervisory failure of the Banco de España has to do with the political control of the cajas ... [T] he supervisor, confronted with powerful and wellconnected ex-politicians decided to look the other way in the face of obvious building trouble. Indeed the political connection of the managers of the entities was a good predictor of brewing trouble."

The experience of Iceland and Spain, among others, also underscores another important point: that credit-fuelled asset bubbles tend to generate a wide political consensus, well beyond the circle of politicians and financiers that originate them. Once the bubble started, the consensus extends to far wider sectors of the population - again a feature common to other countries in the pre-crisis period. Most of society seemed to profit from the bubble, not only bankers earning huge profits and bonuses, but also households reaping high returns on their assets and firms gaining from the boom in business - and of course politicians at the helm of governments basking in popularity. In 2008, Iceland ranked as the 4th country in the world in terms of per capita GDP!

This highlights that politics is a root cause of the hypertrophy of finance, but not just because of political capture of politicians by bankers: the euphoria associated with the bubble creates a vast political support around it, while the few who raise objections against its sustainability are seen as "party-spoilers", to be silenced and sidelined - within banks, within political parties, and most likely even within households. This is a quite general point about economy-wide bubbles: once started, there is no constituency to stop them, because everyone simply tries to grab as large a gain as possible until the bubble lasts. Sadly, this suggests that the "dark side" of finance is hard to separate from a "dark side" of politics and society. 


\section{References}

Acharya, Viral, and Hassan Naqvi (2012), "The Seeds of a Crisis: A Theory of Bank Liquidity and Risk Taking over the Business Cycle," Journal of Financial Economics 106(2), 349-366.

Acharya, Viral, Robert Engle, and Matthew Richardson (2012), "Capital Shortfall: A New Approach to Ranking and Regulating Systemic Risks," American Economic Review Papers and Proceedings 102(3), 59-64.

Acharya, Viral, and Sascha Steffen (2012), "The 'Greatest' Carry Trade Ever? Understanding Eurozone Bank Risks," New University Working Paper.

Adrian, Tobias, and Hyun Song Shin (2010), "The Changing Nature of Financial Intermediation and the Financial Crisis of 2007-2009," Annual Review of Economics 2, 603-18.

Aghion, Philippe, Thibault Fally, and Stefano Scarpetta (2007), "Credit Constraints as a Barrier to the Entry and Post-Entry Growth of Firms," Economic Policy 22(52), October, 731-779.

Arcand, Jean Louis, Enrico Berkes, and Ugo Panizza (2012), “Too Much Finance?" IMF Working Paper No. WP/12/161.

Ashcraft, Adam, Paul Goldsmith-Pinkham, and James Vickery (2010), "MBS Ratings and the Mortgage Credit Boom," Federal Reserve Bank of New York Staff Report 449.

Bar-Isaac, Heski, and Joel Shapiro (2011), "Credit Ratings Accuracy and Analyst Incentives," American Economic Review Papers and Proceedings 101(3), 1-7.

Beck, Thortsen and Asli Demirgüç-Kunt (2009), "Financial Institutions and Markets Across Countries and over Time: Data and Analysis," World Bank Policy Research Working Paper No. 4943, May.

Beck, Thorsten, Ross Levine and Norman Loayza (2000a), "Financial Intermediation and Growth: Causality and Causes," Journal of Monetary Economics 46(1), 31-47.

Beck, Thorsten, Ross Levine and Norman Loayza (2000b), "Finance and the Sources of Growth," Journal of Financial Economics 58(1-2), October/November, 261-300.

Bekaert, Geert, Campbell Harvey, and Chris Lundblad (2005), “Does financial liberalization spur growth?" Journal of Financial Economics 77, 3-55.

Benediktsdottir, Sigridur, Jon Danielsson and Gylfi Zoega (2011), "Lessons from a collapse of a financial system," Economic Policy 26, 66, 183-231.

Bertrand, Marianne, Antoinette Schoar, and David Thesmar (2007), "Banking Deregulation and Industry Structure: Evidence from the French Banking Reforms of 1985," Journal of Finance 62(2), 597-628. 
Bolton, Patrick, Tano Santos and José A. Scheinkman (2012), "Cream skimming in financial markets," Columbia University Working Paper.

Brown, Craig O., and I. Serdar Dinç (2011), "Too Many to Fail? Evidence of Regulatory Forbearance When the Banking Sector Is Weak," Review of Financial Studies 24(4), 1378-1405.

Brownlees, Christian, and Robert Engle (2012), "Volatility, Correlation and Tails for Systemic Risk Measurement," New York University Working Paper.

Čihák, Martin, Aslı Demirgüç-Kunt, Erik Feyen, and Ross Levine (2012), "Benchmarking Financial Development Around the World," Policy Research Working Paper 6175, World Bank.

Cuñat, Vicente, and Luis Garicano (2009), "Did Good Cajas Extend Bad Loans? The Role of Governance and Human Capital in Cajas' Portfolio Decisions", FEDEA monograph.

Dehejia, Rajeev, and Adriana Lleras-Muney (2007), "Financial Development and Pathways of Growth: State Branching and Deposit Insurance Laws in the United States from 1900 to 1940," Journal of Law and Economics 50(2), 239-272.

Dell'Ariccia, Giovanni, and Robert Marquez (2006), "Lending Booms and Lending Standards," Journal of Finance 61, 2511-2546.

Dell'Ariccia, Giovanni, Deniz Igan and Luc Laeven (2012), "Credit Booms and Lending Standards: Evidence from the Subprime Mortgage Market," Journal of Money, Credit and Banking 44, 367-384.

Demirgüc-Kunt, Asli, and Ross Levine (2001), Financial Structure and Economic Growth. A CrossCountry Comparison of Banks, Markets and Development (eds.), MIT Press, Cambridge, MA.

Di Maggio, Marco, and Marco Pagano (2012), "Financial Disclosure and Market Transparency with Costly Information Processing," CSEF Working Paper no. 323 and EIEF Working Paper 12/12.

Ductor, Lorenzo, and Daryna Grechyna (2011), "Excess Financial Development and Economic Growth," SSRN Working Paper, http://ssrn.com/abstract=1997526.

Farhi, Emmanuel, and Jean Tirole (2012), "Collective Moral Hazard, Maturity Mismatch, and Systemic Bailouts," American Economic Review 102(1), 60-93.

Garicano, Luis (2012), "Five Lessons from the Spanish Cajas Debacle for a New Euro-Wide Supervisor," www.voxeu.org, 16 October.

Goldsmith, Raymond W. (1969), Financial Structure and Development, New Haven, CT: Yale University Press.

Greenwood, Robin, and David Scharfstein (2012), "The Growth of Modern Finance," Harvard Business School Working Paper. 
Griffin, John M., and Dragon Yongjun Tang (2010), “Did Credit Rating Agencies Make Unbiased Assumptions on CDOs?" American Economic Review Papers and Proceedings 101(3), 125-130.

Griffin, John M., and Dragon Yongjun Tang (2011), “Did Subjectivity Play a Role in CDO Credit Ratings?" Journal of Finance, forthcoming.

Guiso, Luigi, Tullio Jappelli, Mario Padula and Marco Pagano (2004), "Financial Market Integration and Economic Growth in the EU," Economic Policy 19(40), 523-77.

Guiso, Luigi, Paola Sapienza and Luigi Zingales (2004), “Does Local Financial Development Matter?," Quarterly Journal of Economics 119(3), 929-969.

Gupta, Nandini and Kathy Yuan (2009) "On the Growth Effect of Stock Market Liberalizations," Review of Financial Studies 22 (11), 4715-4752.

Henry, Peter Blair (2000), "Do Stock Market Liberalizations Cause Investment Booms?" Journal of Financial Economics 58, 301-334.

Hicks, John (1969), A Theory of Economic History. Oxford: Clarendon Press, 1969.

Ioannidou, Vasso, Steven Ongena and José-Luis Peydró (2009), "Monetary Policy, Risk-Taking and Pricing: Evidence from a Quasi-Natural Experiment ," European Banking Center Discussion Paper No. 2009-04S.

Jayaratne, Jith, and Philip Strahan (1996), "The Finance-Growth Nexus: Evidence from Bank Branch Deregulation," Quarterly Journal of Economics 111(3), 639-70.

Jiménez, Gabriel, Steven Ongena, José-Luis Peydró and Jesús Saurina (2011), "Hazardous Times for Monetary Policy: What do 23 Million Loans Say About the Impact of Monetary Policy on Credit RiskTaking? ," Working Paper, Tilburg University.

Keynes, John Maynard (1936), The General Theory of Employment, Interest, and Money, Harcourt, Brace, and Co.: New York.

King, Robert G., and Ross Levine (1993a), "Finance and Growth: Schumpeter May be Right," Quarterly Journal of Economics 108(3), 713-737.

King, Robert G., and Ross Levine (1993b), "Finance, Entrepreneurship and Growth," Journal of Monetary Economics 32(3), 513-542.

Klapper, Leora, Luc Laeven and Raghuram Rajan (2006), "Entry Regulation as a Barrier to Entrepreneurship," Journal of Financial Economics 82(3), 591-629.

Kroszner, Randall S., Luc Laeven and Daniela Klingebiel (2007), "Banking Crises, Financial Dependence, and Growth," Journal of Financial Economics 84, 187-228. 
La Porta, Rafael, Florencio Lopez-de-Silanes, and Andrei Shleifer (1998), "Law and Finance," Journal of Political Economy 106(6), 1113-55.

Levine, Ross (1997), "Financial Development and Economic Growth: Views and Agenda," Journal of Economic Literature 35, 688--726.

Levine, Ross (2005), "Finance and Growth: Theory and Evidence," in Handbook of Economic Growth, Philippe Aghion and Steven Durlauf editors, The Netherlands: Elsevier Science.

Maddaloni, Angela, and José-Luis Peydró (2011), "Bank Risk-Taking, Securitization, Supervision, and Low Interest Rates: Evidence from the Euro Area and U.S. Lending Standards," Review of Financial Studies 24, 2121-65.

Pagano, Marco (1993), "Financial Markets and Growth: an Overview," European Economic Review $37(2 / 3), 613-622$.

Pagano, Marco, and Giovanni Pica (2012), “Finance and Employment," Economic Policy 27, 69, 7-55.

Pagano, Marco, and Paolo Volpin (2010), "Credit Ratings Failures and Policy Options," Economic Policy $25,62,403-431$.

Pagano, Marco, and Paolo Volpin (2012), "Securitization, Disclosure and Liquidity," Review of Financial Studies 25(8), 2417-2453.

Philippon, Thomas (2008), "The Evolution of the US Financial Industry from 1860 to 2007: Theory and Evidence," NYU-Stern Working Paper.

Philippon, Thomas, and Ariell Reshef (2008) "Wages and Human Capital in the U.S. Financial Industry: 1909-2006," Quarterly Journal of Economics, forthcoming.

Pozsar, Zoltan, Tobias Adrian, Adam Ashcraft, and Hayley Boesky (2010), "Shadow Banking," Federal Reserve Bank of New York Staff Reports, no. 458, July, revised in February 2012.

Rajan, Raghuram G. and Luigi Zingales (1998), “Financial Dependence and Growth,” American Economic Review 88(3), 559-587. 


\section{Table 1. Financial development and output growth}

The dependent variable is the percentage growth rate of value added in the relevant country and industry. The estimation period is 1970-2004. Industry's share in 1970 refers to total value added. Robust standard errors are reported in parentheses. One, two and three asterisks denote coefficients significant at the $10 \%, 5 \%$ and $1 \%$ level, respectively. The estimates are drawn from Table 1 in Pagano and Pica (2012).

\begin{tabular}{|c|c|c|c|c|c|c|}
\hline Explanatory & \multicolumn{2}{|c|}{ All countries } & \multicolumn{2}{|c|}{ OECD countries } & \multicolumn{2}{|c|}{ Non-OECD countries } \\
\hline $\begin{array}{l}\text { Industry's share } \\
\text { in } 1970\end{array}$ & $\begin{array}{c}-0.156^{* * *} \\
(0.030)\end{array}$ & $\begin{array}{c}-0.204^{* * *} \\
(0.027)\end{array}$ & $\begin{array}{c}-0.212^{* * *} \\
(0.054)\end{array}$ & $\begin{array}{c}-0.212^{* * *} \\
(0.055)\end{array}$ & $\begin{array}{c}-0.161^{* * *} \\
(0.032)\end{array}$ & $\begin{array}{r}-0.213^{* * *} \\
(0.030)\end{array}$ \\
\hline $\begin{array}{l}\text { External } \\
\text { dependence } \times \\
\text { stock market } \\
\text { capitalization (80- } \\
95 \text { ) }\end{array}$ & $\begin{array}{l}0.026^{*} \\
(0.014)\end{array}$ & & $\begin{array}{l}-0.022 \\
(0.018)\end{array}$ & & $\begin{array}{l}0.037^{* *} \\
(0.016)\end{array}$ & \\
\hline $\begin{array}{l}\text { External } \\
\text { dependence } \times \\
\text { claims of banks } \\
\text { and other fin. } \\
\text { inst. }(80-95)\end{array}$ & & $\begin{array}{l}0.034^{* *} \\
(0.016)\end{array}$ & & $\begin{array}{l}-0.011 \\
(0.011)\end{array}$ & & $\begin{array}{l}0.091^{* *} \\
(0.036)\end{array}$ \\
\hline Observations & 1533 & 1637 & 628 & 628 & 905 & 1009 \\
\hline$R^{2}$ & 0.32 & 0.33 & 0.48 & 0.48 & 0.30 & 0.32 \\
\hline
\end{tabular}


Table 2. Credit market size and creditworthiness of banks

The dependent variable is the Z-score, estimated as the sum of banks' ROA and equity/assets ratio, divided by the standard deviation of ROA. Credit/GDP is the ratio of private credit by deposit money banks and other financial institutions to GDP. All regressions include fixed country effects and calendar year effects. The maximum estimation period is 1997-2010 in all three regressions. One, two and three asterisks denote coefficients significant at the $10 \%, 5 \%$ and $1 \%$ level, respectively.

\begin{tabular}{l|c|c|c|}
\hline \multicolumn{1}{c|}{ Explanatory variable: } & All countries & $\begin{array}{c}\text { Countries with } \\
\text { credit/GDP }<50 \%\end{array}$ & $\begin{array}{c}\text { Countries with } \\
\text { credit/GDP }>50 \%\end{array}$ \\
\hline Credit/GDP & $-0.111^{* * *}$ & -0.055 & $-0.116^{* * *}$ \\
Observations & $(0.014)$ & $(0.055)$ & $(0.014)$ \\
Countries & 2,048 & 1073 & 975 \\
& 166 & 88 & 78 \\
\hline$R^{2}$ & 0.61 & 0.51 & 0.64 \\
\hline
\end{tabular}

Table 3. Credit market size and systemic risk

The dependent variable is an estimate of the capital shortfall that all the banks in a given country and year are expected to incur in a financial crisis, scaled by their total market capitalization. The estimate of the capital shortfall is based on Brownlees and Engle (2011) and Acharya, Engle and Richardson (2012), and its country-level values have been produced by VLab at NYU and kindly provided by Viral Acharya and Robert Capellini. Credit/GDP is the ratio of private credit by deposit money banks and other financial institutions to GDP. All regressions include fixed country effects and calendar year effects. The maximum estimation period is 2000-2011 in all three regressions. One, two and three asterisks denote coefficients significant at the $10 \%, 5 \%$ and $1 \%$ level, respectively.

\begin{tabular}{l|c|c|c}
\hline \multicolumn{1}{c|}{ Explanatory variable: } & All countries & $\begin{array}{c}\text { Countries with } \\
\text { credit/GDP }<50 \%\end{array}$ & $\begin{array}{c}\text { Countries with } \\
\text { credit/GDP }>50 \%\end{array}$ \\
\hline Credit/GDP & $0.009^{* * *}$ & -0.024 & $0.0078^{* *}$ \\
Observations & $(0.003)$ & $(0.033)$ & $(0.002)$ \\
Countries & 353 & 51 & 302 \\
\hline$R^{2}$ & 46 & 10 & 36 \\
\hline
\end{tabular}


Figure 1. Bank creditworthiness and credit/GDP in selected countries with credit/GDP $<50 \%$

\section{Panel A}
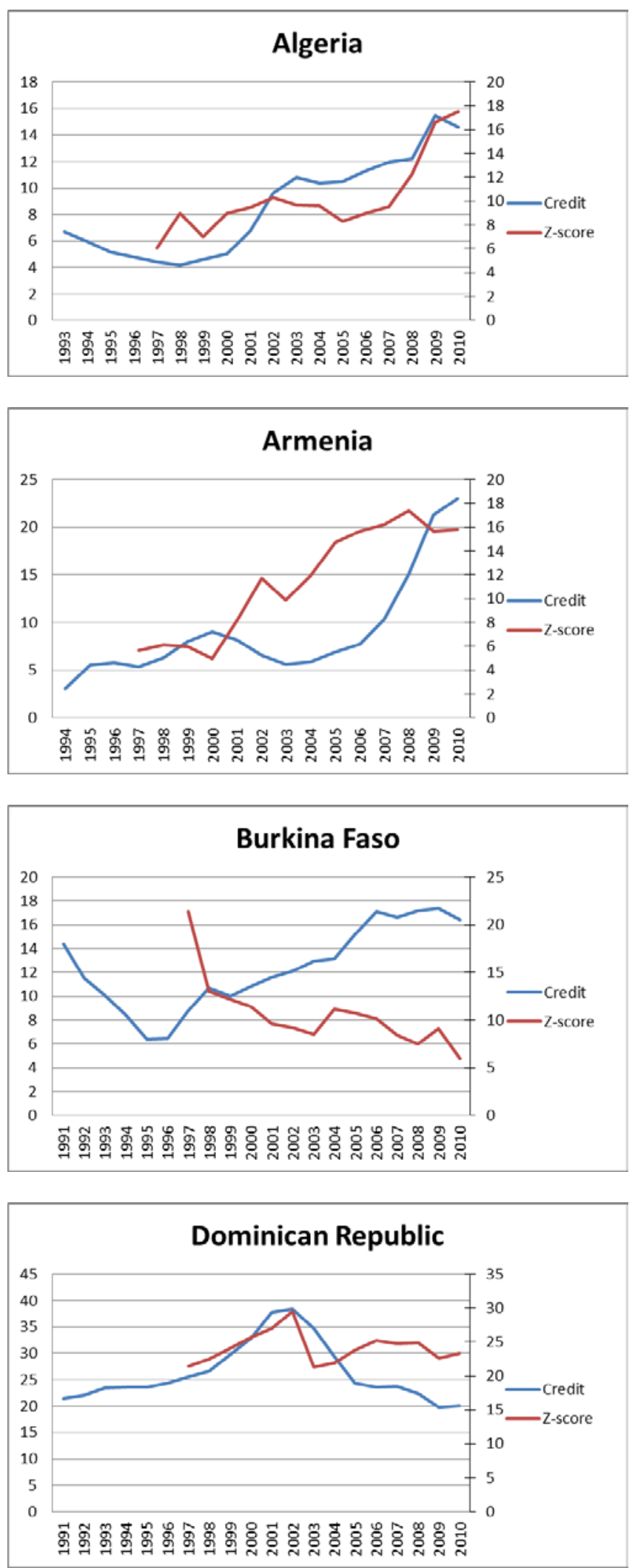
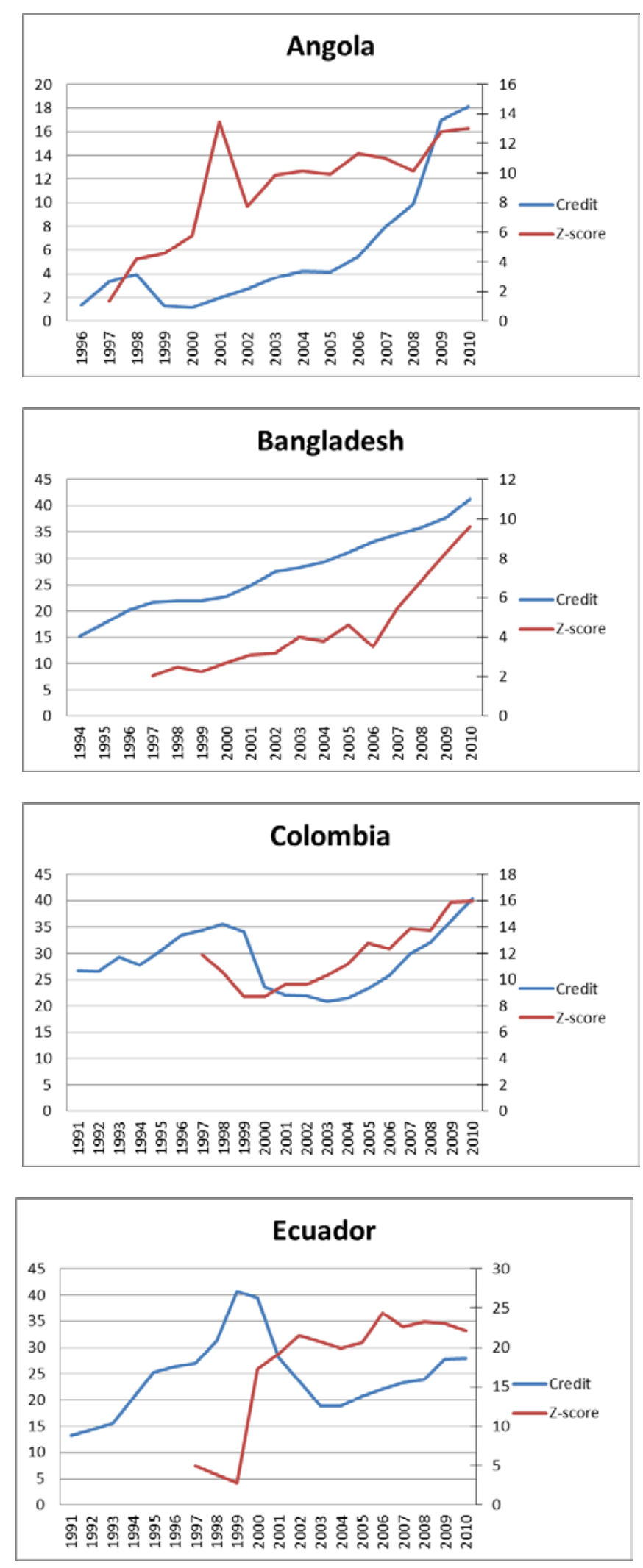
Figure 1. Bank creditworthiness and credit/GDP in selected countries with credit/GDP $<50 \%$

\section{Panel B}
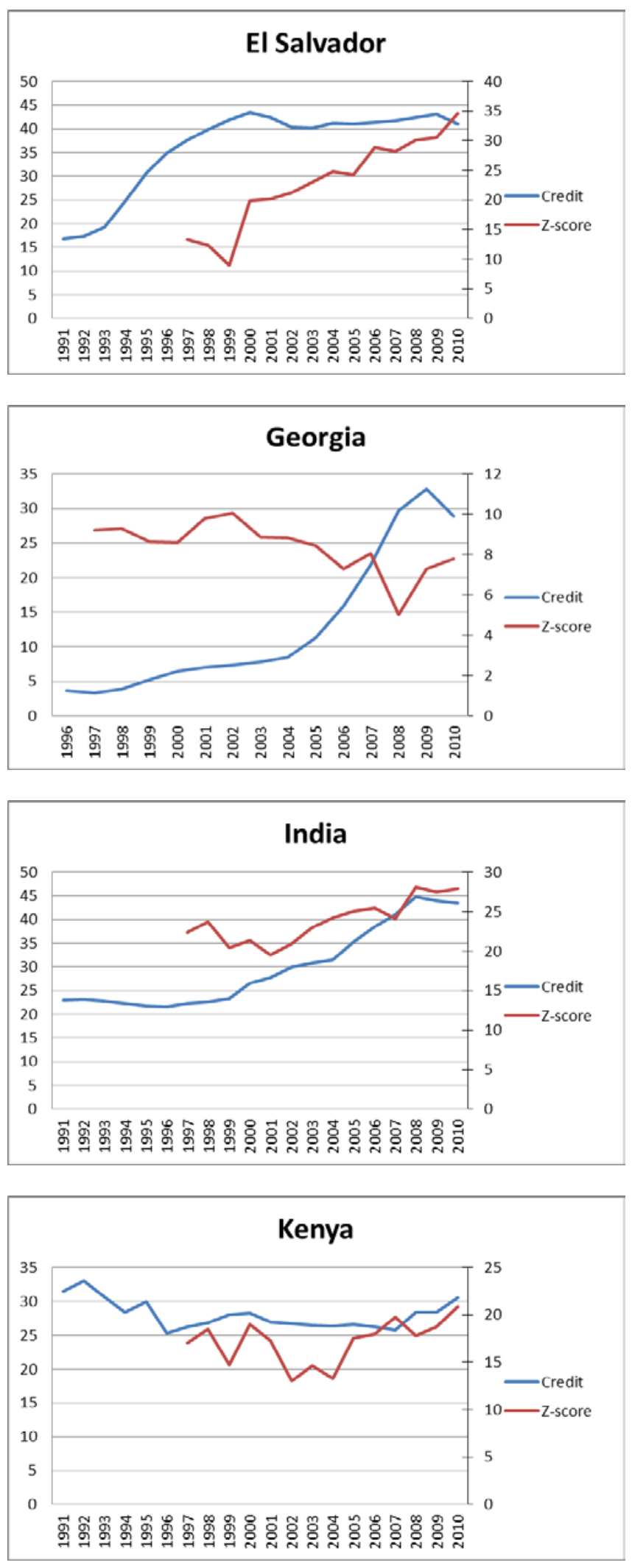
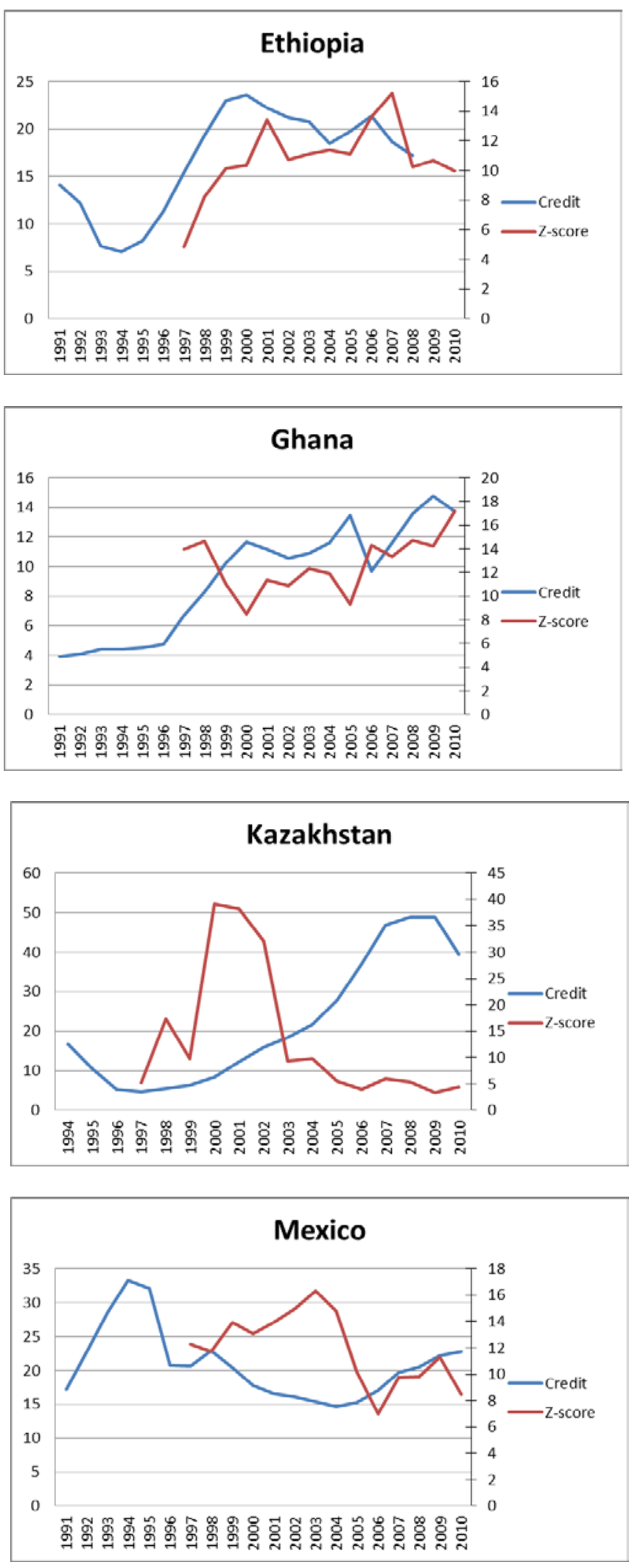
Figure 1. Bank creditworthiness and credit/GDP in selected countries with credit/GDP $<50 \%$

\section{Panel C}
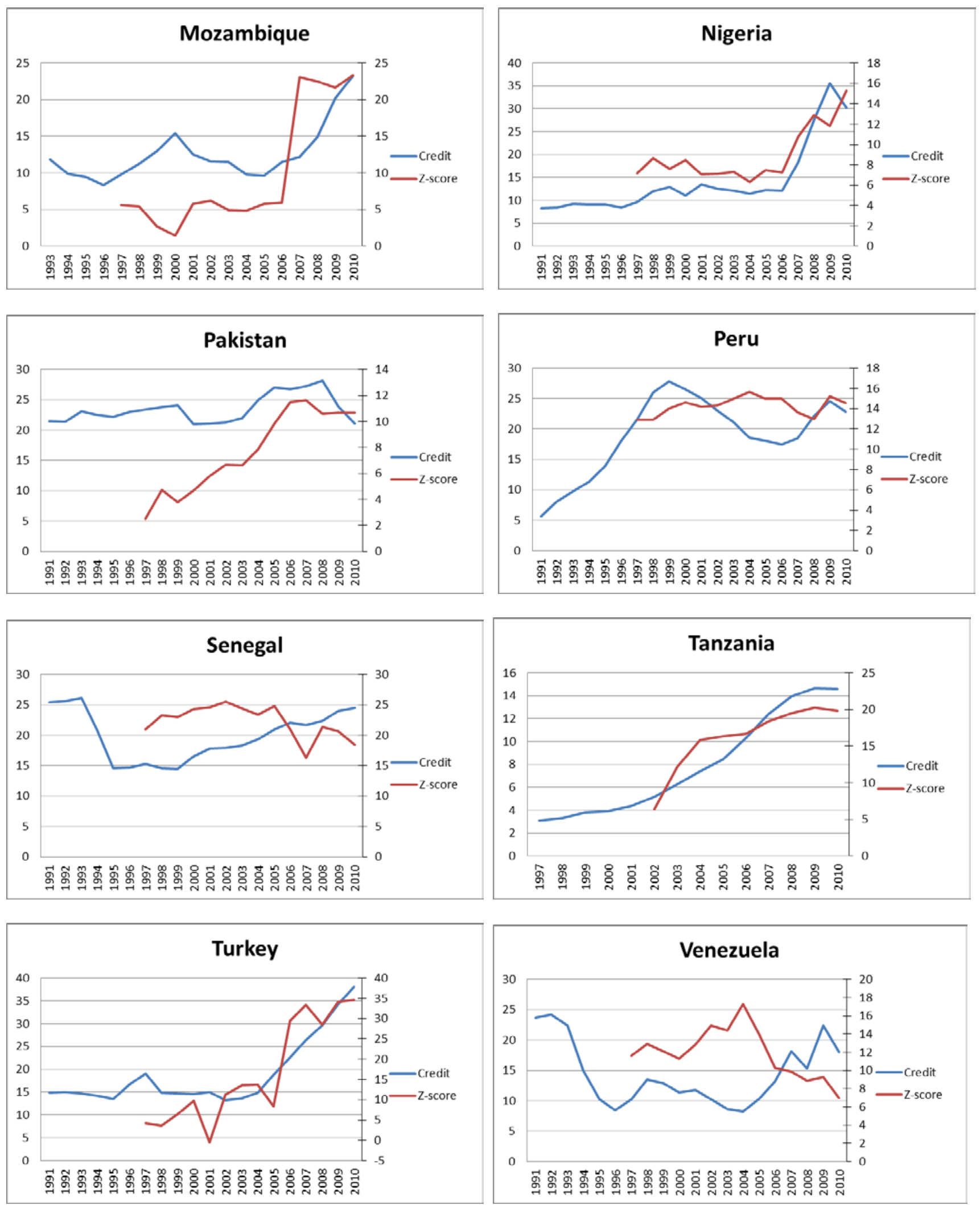
Figure 2. Bank creditworthiness and credit/GDP in selected countries with credit/GDP $>50 \%$

\section{Panel A}
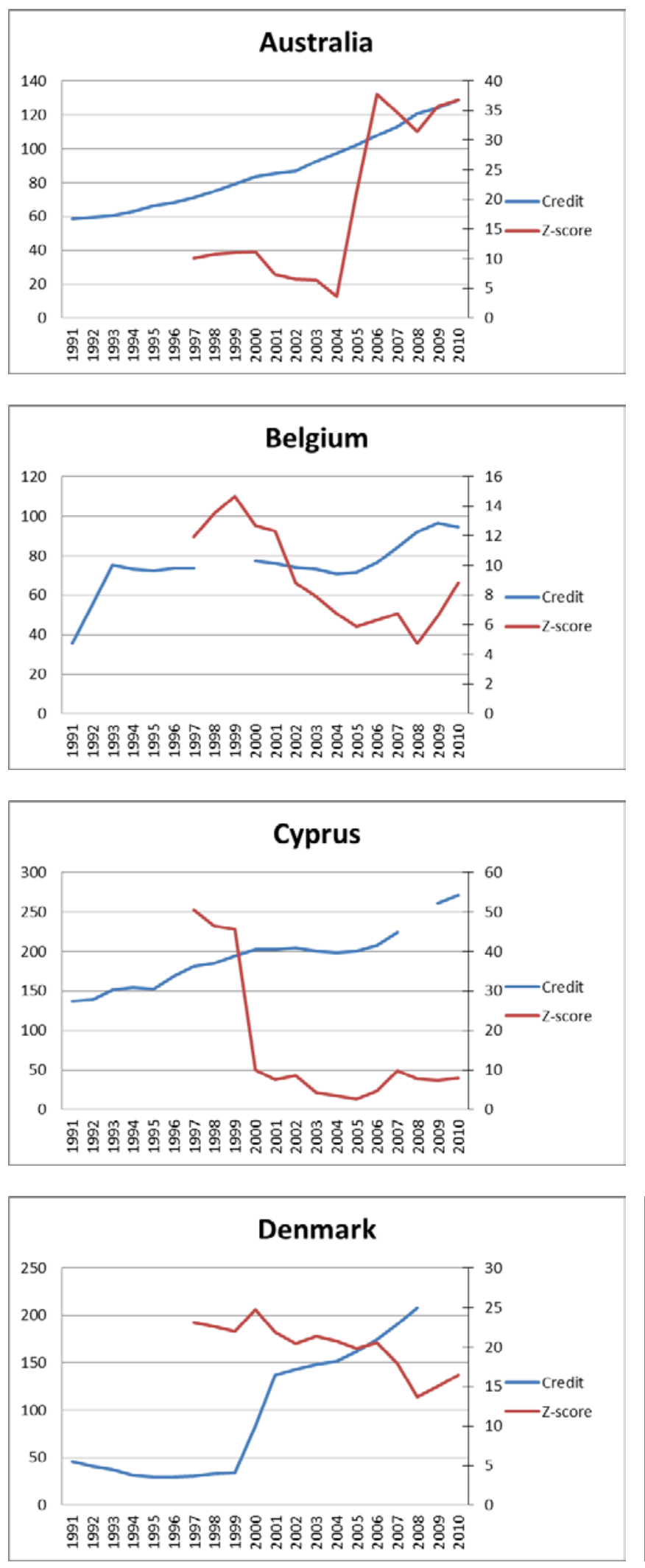
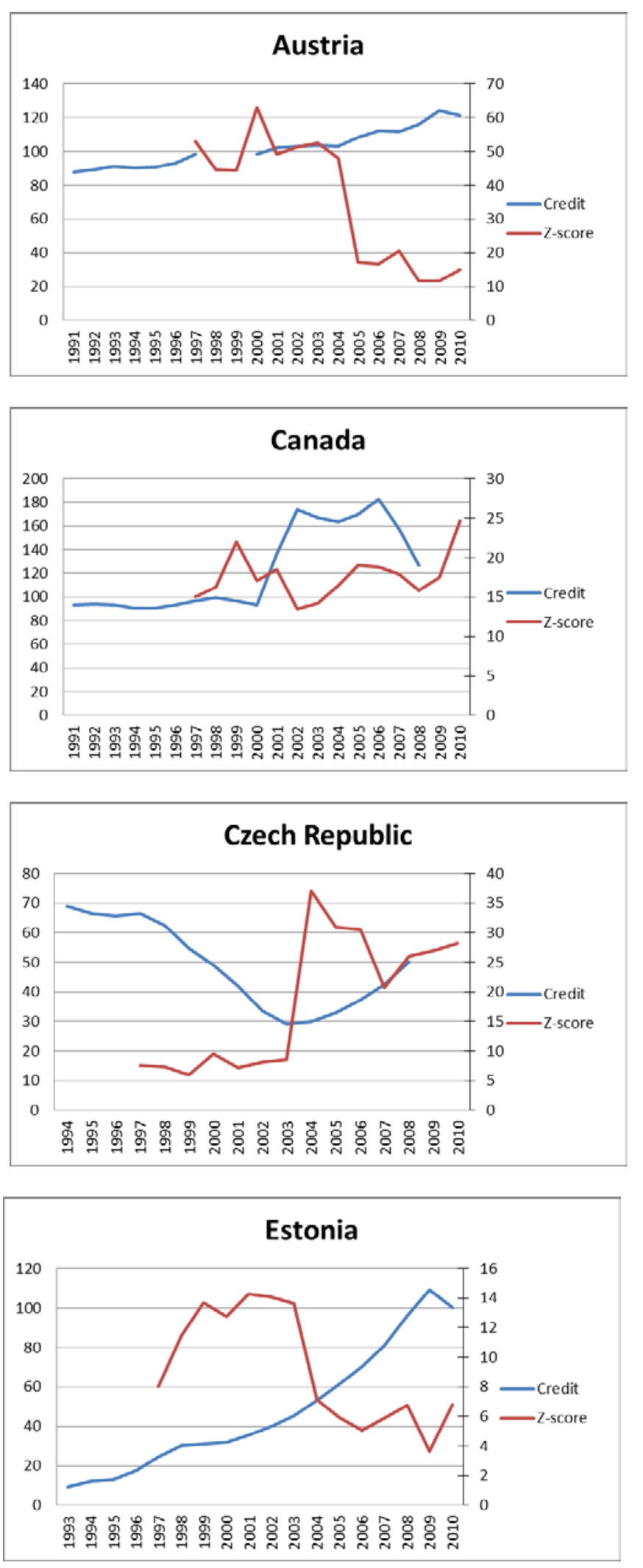
Figure 2. Bank creditworthiness and credit/GDP in selected countries with credit/GDP $>50 \%$

\section{Panel B}
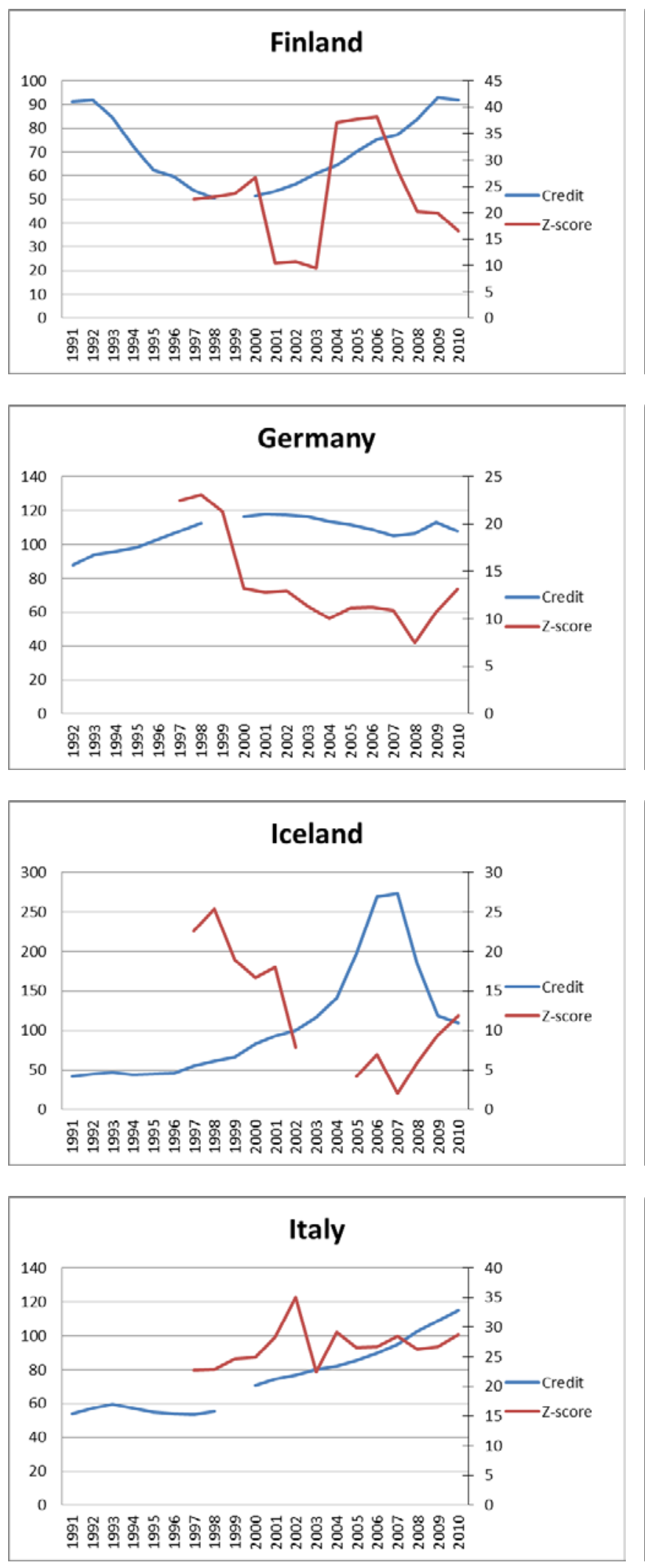
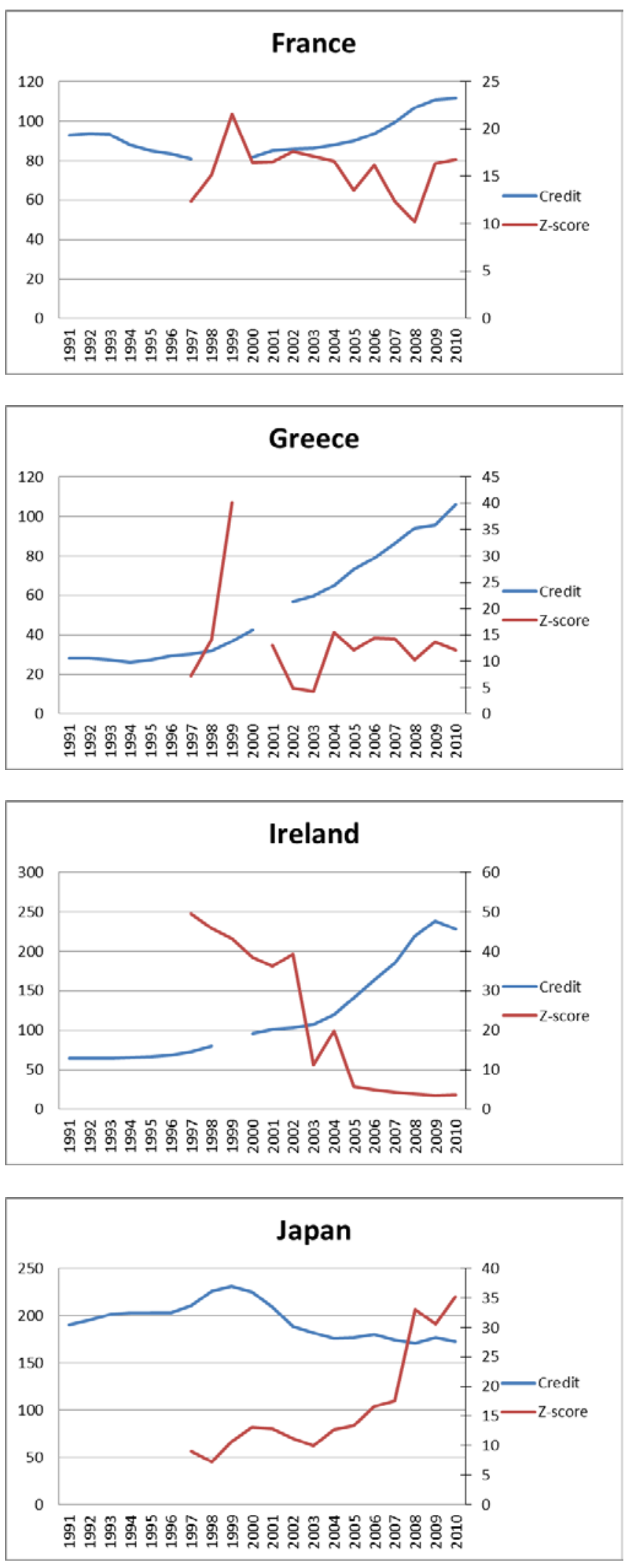
Figure 2. Bank creditworthiness and credit/GDP in selected countries with credit/GDP $>50 \%$

\section{Panel C}
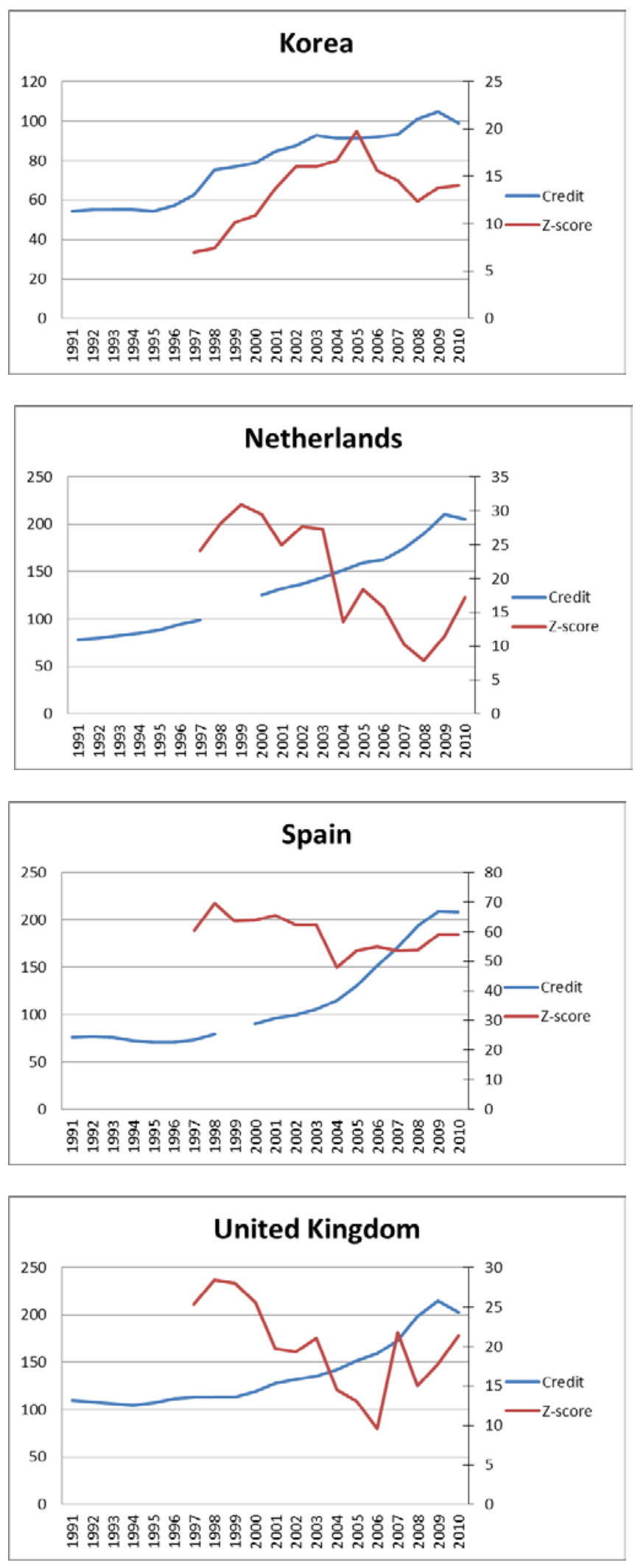
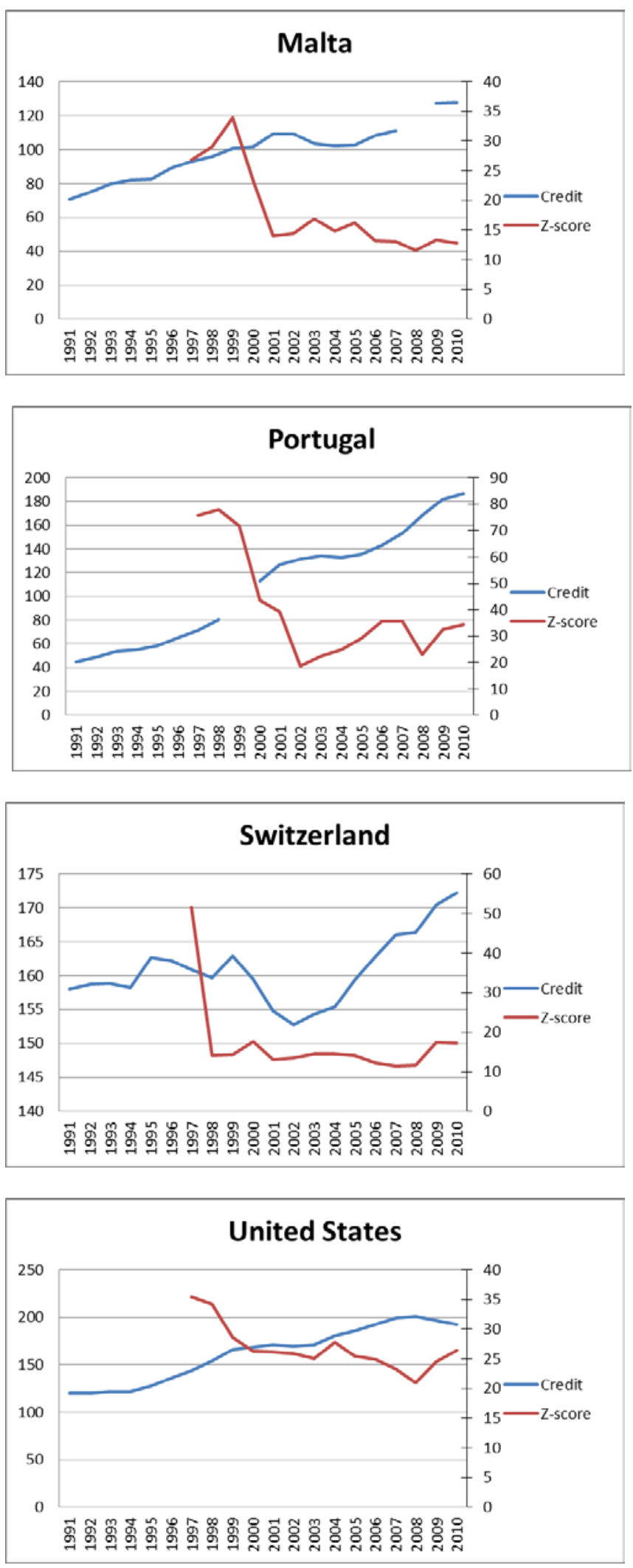
Appendix 1. Countries included in the regressions of Tables 2

\begin{tabular}{|c|c|c|c|}
\hline \multicolumn{4}{|c|}{ Countries with credit/GDP $<50 \%$} \\
\hline list & observations & list & observations \\
\hline Afghanistan & 3 & Macedonia, FYR & 14 \\
\hline Albania & 14 & Madagascar & 14 \\
\hline Algeria & 14 & Malawi & 14 \\
\hline Angola & 14 & Mali & 14 \\
\hline Argentina & 14 & Mauritania & 5 \\
\hline Armenia & 14 & Mexico & 14 \\
\hline Azerbaijan & 14 & Moldova & 14 \\
\hline Bangladesh & 14 & Mongolia & 12 \\
\hline Belarus & 14 & Mozambique & 14 \\
\hline Benin & 14 & Myanmar & 12 \\
\hline Bhutan & 14 & Namibia & 8 \\
\hline Botswana & 14 & Nepal & 14 \\
\hline Burkina Faso & 14 & Nicaragua & 10 \\
\hline Burundi & 14 & Niger & 14 \\
\hline Cambodia & 11 & Nigeria & 14 \\
\hline Cameroon & 14 & Oman & 8 \\
\hline Central African Republic & 12 & Pakistan & 14 \\
\hline Chad & 12 & Papua New Guinea & 12 \\
\hline Colombia & 14 & Paraguay & 14 \\
\hline Congo, Dem. Rep. & 9 & Peru & 14 \\
\hline Congo, Rep. & 4 & Poland & 13 \\
\hline Costa Rica & 14 & Romania & 14 \\
\hline Cote d'Ivoire & 14 & Russian Federation & 14 \\
\hline Djibouti & 10 & Rwanda & 10 \\
\hline Dominica & 6 & Samoa & 14 \\
\hline Dominican Republic & 14 & Senegal & 14 \\
\hline Ecuador & 14 & Serbia & 12 \\
\hline El Salvador & 14 & Seychelles & 8 \\
\hline Equatorial Guinea & 7 & Sierra Leone & 14 \\
\hline Ethiopia & 13 & Sri Lanka & 14 \\
\hline Gabon & 14 & St. Vincent and the Grenadines & 3 \\
\hline Gambia, The & 13 & Sudan & 14 \\
\hline Georgia & 14 & Suriname & 14 \\
\hline Ghana & 14 & Swaziland & 14 \\
\hline Guatemala & 14 & Syrian Arab Republic & 12 \\
\hline Haiti & 14 & Tajikistan & 6 \\
\hline India & 14 & Tanzania & 9 \\
\hline Iraq & 2 & Togo & 14 \\
\hline Jamaica & 13 & Trinidad and Tobago & 14 \\
\hline Kazakhstan & 14 & Turkey & 14 \\
\hline Kenya & 14 & Uganda & 14 \\
\hline Kyrgyz Republic & 9 & Venezuela, RB & 14 \\
\hline Lesotho & 12 & Yemen, Rep. & 9 \\
\hline Liberia & 4 & Zambia & 14 \\
\hline
\end{tabular}


Appendix 1. Countries included in the regressions of Tables 2

\begin{tabular}{|c|c|c|c|}
\hline \multicolumn{4}{|c|}{ Countries with credit/GDP > 50\% } \\
\hline list & observations & list & observations \\
\hline Antigua and Barbuda & 8 & Jordan & 14 \\
\hline Aruba & 7 & Korea, Rep. & 14 \\
\hline Australia & 14 & Kuwait & 14 \\
\hline Austria & 12 & Latvia & 13 \\
\hline Bahamas, The & 14 & Lithuania & 14 \\
\hline Bahrain & 7 & Luxembourg & 12 \\
\hline Barbados & 14 & Macao SAR, China & 14 \\
\hline Belgium & 12 & Malaysia & 14 \\
\hline Belize & 12 & Maldives & 4 \\
\hline Bolivia & 14 & Malta & 13 \\
\hline Bosnia and Herzegovina & 3 & Mauritius & 14 \\
\hline Brazil & 14 & Montenegro & 4 \\
\hline Brunei Darussalam & 9 & Morocco & 14 \\
\hline Bulgaria & 13 & Netherlands & 12 \\
\hline Canada & 13 & New Zealand & 14 \\
\hline Cape Verde & 11 & Norway & 11 \\
\hline Chile & 13 & Panama & 14 \\
\hline China & 14 & Philippines & 14 \\
\hline Croatia & 14 & Portugal & 13 \\
\hline Cyprus & 13 & San Marino & 6 \\
\hline Czech Republic & 13 & Saudi Arabia & 14 \\
\hline Denmark & 13 & Singapore & 14 \\
\hline Egypt, Arab Rep. & 14 & Slovak Republic & 13 \\
\hline Estonia & 14 & Slovenia & 13 \\
\hline Finland & 13 & South Africa & 14 \\
\hline France & 12 & Spain & 13 \\
\hline Germany & 13 & St. Kitts and Nevis & 14 \\
\hline Greece & 12 & St. Lucia & 14 \\
\hline Grenada & 14 & Sweden & 13 \\
\hline Guyana & 14 & Switzerland & 14 \\
\hline Honduras & 14 & Thailand & 14 \\
\hline Hong Kong SAR, China & 14 & Tunisia & 14 \\
\hline Hungary & 13 & Ukraine & 14 \\
\hline Iceland & 12 & United Kingdom & 14 \\
\hline Indonesia & 14 & United States & 14 \\
\hline Ireland & 13 & Uruguay & 14 \\
\hline Israel & 14 & Vanuatu & 9 \\
\hline Italy & 13 & Vietnam & 14 \\
\hline Japan & 14 & Zimbabwe & 6 \\
\hline
\end{tabular}


Appendix 2. Countries included in the regressions of Tables 3

\begin{tabular}{|l|c|l|c|}
\hline \multicolumn{4}{|c|}{ Countries with credit/GDP <50\% } \\
\hline \multicolumn{1}{|c|}{ list } & observations & \multicolumn{1}{c|}{ list } & observations \\
\hline Argentina & 8 & Peru & 3 \\
India & 12 & Philippines & 2 \\
Indonesia & 4 & Poland & 6 \\
Kazakhstan & 2 & Russian Federation & 2 \\
Mexico & 6 & Turkey & 6 \\
\hline
\end{tabular}

\begin{tabular}{|l|c|l|c|}
\hline \multicolumn{4}{|c|}{ Countries with credit/GDP >50\% } \\
\hline \multicolumn{1}{|c|}{ list } & observations & \multicolumn{1}{|c|}{ list } & observations \\
\hline Australia & 11 & Korea, Rep. & 12 \\
Austria & 10 & Luxembourg & 4 \\
Belgium & 11 & Malaysia & 12 \\
Brazil & 10 & Malta & 2 \\
Canada & 10 & Mauritius & 3 \\
Chile & 6 & Netherlands & 11 \\
China & 7 & Norway & 8 \\
Cyprus & 6 & Portugal & 5 \\
Denmark & 9 & Saudi Arabia & 2 \\
Finland & 7 & Singapore & 2 \\
France & 11 & South Africa & 12 \\
Germany & 11 & Spain & 5 \\
Greece & 11 & Sweden & 10 \\
Hong Kong SAR, China & 6 & Switzerland & 12 \\
Ireland & 6 & Thailand & 11 \\
Israel & 12 & United Kingdom & 11 \\
Italy & 10 & United States & 12 \\
Japan & 12 & Vietnam & 2 \\
\hline
\end{tabular}

